\title{
A note on Nectandra (Lauraceae), with the description of a new species
}

\author{
Klaus Kubitzki (")
}

\begin{abstract}
The author describes a new species of Lauraceae from Amazonia, Nectandra spumea Kubitzki sp. n., and gives critical comments on the possible distinctions among the genera Ocotea, Nectandra and Pleurothyrium, especially between the first two.
\end{abstract}

The species described in this paper is somewhat intermediate between the genera Nectandra and Ocotea. The principal character for separating these large genera is the position of the anther cells which in the latter genus are arranged in pairs above each other, and in the former in an arc. Kostermans (1952: 149; 1957: 232) does not consider this difference as sufficient for generic separation and combines the two genera together with Pleurothyrium, maintaining however, subgeneric status for all of them. Bernardi $(1962.96,184)$ agrees with Kostermans that with regard to certain species the separation of the genera Ocotea and Nectandra indeed is difficult, and that the character used for their separation, namely the arrangement of the anther cells, is not of great taxonomic importance. However, for pragmatic reasons, (size and importance of the two genera; relative ease in recognizing most species of Nectandra even in the field), Bernardi prefers to keep them distinct, while supporting the inclusion of Pleurothyrium in Ocotea.

My personal view (suported by the recent studies of bark and wood anatomy by Richter, 1980 ) is that all three genera, irrespective to their size difference, are extremely diverse, and the smallest one, Pleurothyrium, may wel! be the most heterogeneous one, being kept together only by the existence of triglandulate stamens of whorls I-III. The core of Nectan$d r a$, on the other hand, is a very homogeneous assemblage characterized, i. a., by the (*) - University of Hamburg - Federal Republic of Germany. presence of arcuately nerved leaves covered with a dense and minute indumentum, and by reflexed, papillose tepals. There are, however, several species which vegetatively and even with regard to floral characters come close to Ocotea but maintain the arc-like position of the anther celis (at least in the outer stamen whorl), as the species described in the present paper and Nectandra rubriflora (Mez) Allen. discussed and figured by Bernardi (1967).

It is more than questionable whether a satisfactory separation of the two large genera Ocotea and Nectandra can be reached by relying on one character only; what seems possible and necessary to me is to define naturally circumscribed entities to which possibly subgeneric rank could be given by taking into consideration ail potential characters. What can be predicted with certainly is the disappearance of the genus Pleurothyrium since its species partly belong to what at present is Ocotea, partly is Nectandra.

Nectandra spumea Kubitzki, nov. spec.

Type: Brazil. Amazonas. Upper rio Negro region, rio Tea, ca. $40 \mathrm{~km}$ above mouth; tree in flooded blackwater forest, ca. $3 \mathrm{~m}$ high, trunk $8 \mathrm{~cm}$ diam., crown very broad: K. Kubitzki, H. H. Poppendieck \& C. Calderon 79-231, fl, y fr (INPA; isot.: HBG, IAN, M, RB, US).

Arbor ca. $3 \mathrm{~m}$ alta; ramuli novelli puberuli mox glabrescentes; cicatrices depresseobovatae; gemmae terminaies inconspicuae, sericeae. Folia spiraliter inserta, ad extremos ramulorum congesta, subcoriacea, lanceolata vel obovato-lanceolata, apice rotundata vel obtusa, nonnumquam brevissime (per 1-2 mm) acuminata, margine plana incrassata, basi acuta et in petiolum angustata, penninervia, utrimque glabra, supra nitida, subtus opaca, $4-7 \mathrm{~cm}$ longa et $1,5-3 \mathrm{~cm}$ lata, nervis adscen- 


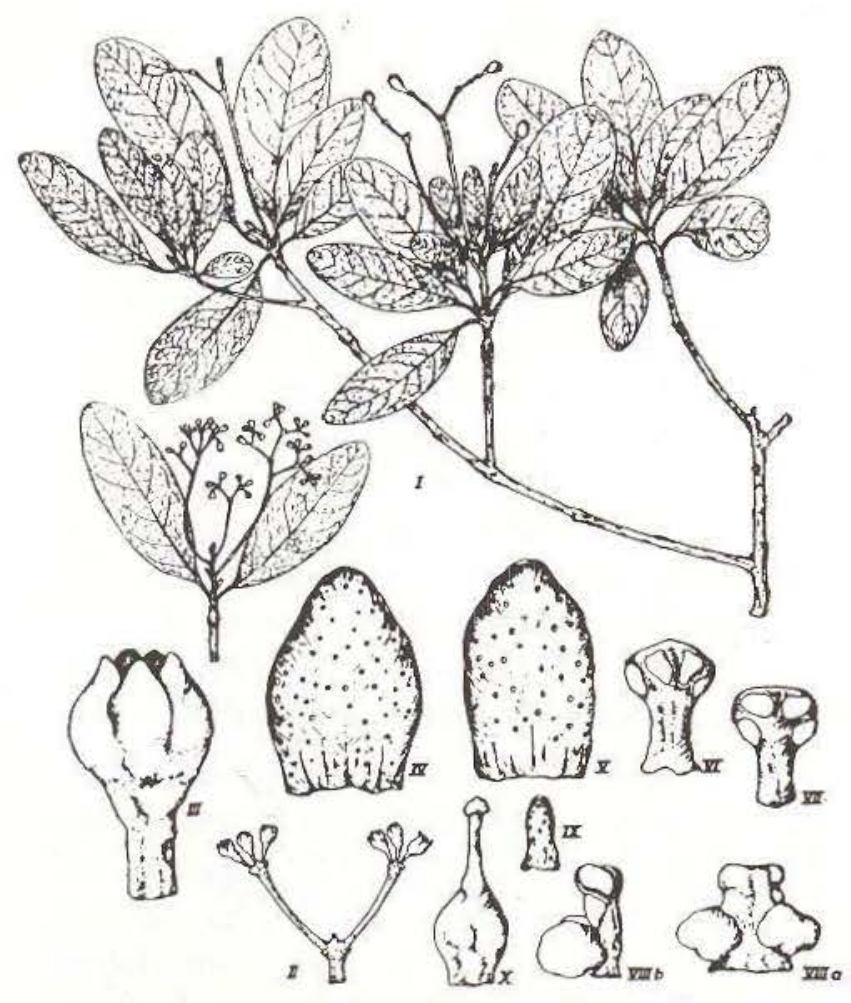

Fig. 1 - Nectandra spumea (from type). I, habit, $\times 1 / 3$; II, distal part of inflorescence, $\times 1$ 1,25; III, flower, $\times$ 9; IV, V, outer and inner tepal, ventral side; VI, VII, stamens of whorl I and II, ventral side; VIII, stamen of whorl III, a, dorsal view, b, lateral view; IX, staminode of whorl IV; X, pistil; IV.X $\times 18$.

dentibus 7 - 9 paribus praeter marginem confluentibus venisque reticulatis praedita; petioli semiteretes, minutissime puberuli, $0.6-1 \mathrm{~cm}$ longi. Paniculae solitariae in axillis folium subapicalium dispositae, glabrae, ca. $4 \mathrm{~cm}$ longae, pedunculis $3-4 \mathrm{~cm}$ longis apice dichasiis instructis et bracteis fugacissimis ca. $1 \mathrm{~mm}$ longis lanceatis praeditae; flores hermaphroditi, ovoidei, glabri, ca. $2.5 \mathrm{~mm}$ longi et $2 \mathrm{~mm}$ lati; tubus latus, interne sericeus; tepala acuta, $1.5 \mathrm{~mm}$ longa, interne pellucido-punctata, basi setosa aliter glabra, anthesi erecta; stamina glabra, ca. $0.7 \mathrm{~mm}$ longa, exteriora introrsa filamentis angustioribus longicribusque quam antheris praedita, verticilli I antheris late obtusis locellis 4 arcuatim dispositis verticilli II antheris truncatis locellis in paribus superpositis praedita, verticilli III antheris haud in filamentis constrictis biglandulosis locellis lateralibus superpositis praedita, staminodia verticilli IV stipitiformia, $0.4 \mathrm{~mm}$ longa, ventraliter sulcata, glabra; pistillum glabrum, $1.2 \mathrm{~mm}$ longum, ovario ellipsoideo stylo aequante stigmate inconspicuo praeditum. Fructus solitarii in infructescentibus, bacca ellipsoidea, immatura viridis, ca. $1 \mathrm{~mm}$ longa, per $1 / 3$ in cupula turbinata rubra ca. $0.8 \mathrm{~cm}$ longa immersa.

This tree contains in its leaves a striking foamy substance alluded to in the specific epithet.

\section{Resumo}

O autor descreve uma nova espécie de Lauraceae da Amazônia, Nectandra spumea Kubitzki sp. n., e tece comentários criticos sobre as possiveis distinçōes dos gêneros Ocotea, Nectandra e Pleurothyrium, em especial dos dois primeiros.

\section{REFERENCES}

BERNARDI, L.

1962 - Lauráceas. Mérida. 335 p.

1967 - Candollea, 22: 91-101.

KOSTERMANS, A.J.G.H.

1952 - J. Scient. Research Indonesia, 1: 141-159.

1957 - Reiwardtia, 4: 193-256.

RICHTER, H.G.

1980 - Holz - und rindenanatomische Untersuchungen an Lauraceen. Doctoral thesis, University of Hamburg.

(Aceito para publicação em 20/10/80) 